\title{
Multifunctional Hydrolytic Catalyses. XI. The Hydrolysis of $p$-Nitrophenyl Acetate by a Polysoap-Bound Bifunctional Catalyst*
}

\author{
Toyoki KUnITAKE and Tetsuo SAKAMOTO \\ Department of Organic Synthesis, Faculty of Engineering, \\ Kyushu University, Fukuoka 812, Japan.
}

(Received May 21, 1979)

\begin{abstract}
The catalytic hydrolysis of $p$-nitrophenyl acetate was studied in water at $30^{\circ} \mathrm{C}$ in the presence of a polysoap-bound bifunctional (LIMHA) catalyst. The polysoaps used were poly(vinylimidazole) quaternized with dodecyl and ethyl groups and poly(ethylenimine) partly quaternized with methyl and higher alkyl $\left(\mathrm{C}_{8}, \mathrm{C}_{12}, \mathrm{C}_{18}\right)$ groups. The catalysis proceeded via the acetyl transfer to the dissociated hydroxamate unit of the bifunctional catalyst and the subsequent decomposition of the intermediate by the neighboring imidazole. Catalysis was promoted well in the hydrophobic domain of the polysoap, but was less than that in the conventional cationic micelle of hexadecyltrimethylammonium bromide. The efficiency of the polysoap-bound bifunctional catalyst was $c a .1000$ times greater than that of imidazole.

KEY WORDS Catalytic Hydrolysis / Bifunctional Catalysis / Phenyl Ester /

Polysoap / Hydroxamic Acid / Imidazole /
\end{abstract}

In the catalytic hydrolysis of phenyl esters, various combinations of catalytic groups have been examined to find efficient catalysis. ${ }^{1}$ The combination of hydroxamate and imidazole is especially interesting, because of its enhanced catalytic activity due to the cooperative action of these functional groups, which is similar to that of the charge relay system at the active site of serine proteases. ${ }^{2-5}$ The nucleophilic reactivity of these catalytic functions is remarkably enhanced in the hydrophobic environment of cationic micelles and consequently, the catalytic efficiency of the bifunctional(hydroxamate-imidazole) system is further increased in the hexadecyltrimethylammonium bromide (CTAB) micelle. ${ }^{5}$

Polysoaps, such as polyamines quaternized by long alkyl chains, combine within a molecule structural characteristics of the conventional micelles and polyelectrolytes, and adopt compact conformations in aqueous media. It is thus expected that the polysoap system has an advantage over the conventional micellar system in bifunctional catalysis. The general microenvironmental effect of polysoaps on decarboxylation reaction has been reported

* Contribution No. 496 from this department. elsewhere. ${ }^{6}$

In this paper, we report on the hydrolysis of $p$ nitrophenyl acetate (PNPA) by a bifunctional catalyst, $N$-lauryl-4-imidazolcarbo hydroxamic acid (LIMHA) and a related monofunctional catalyst, $N$ laurylbenzohydroxamic acid (LBHA), in the presence of several kinds of polysoaps.

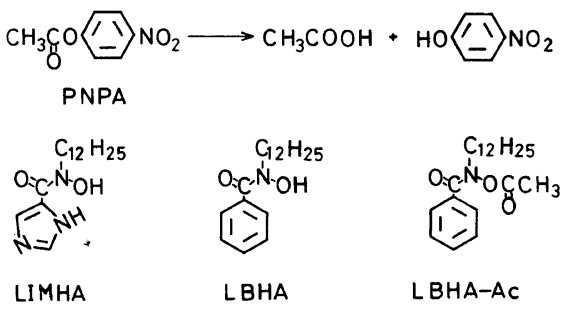

The polysoaps structures used given are as follows.

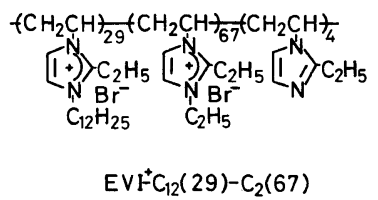




\section{T. Kunitake and T. SAKAmoto}

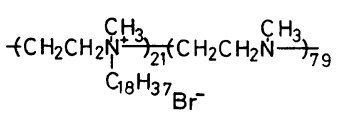

$\mathrm{PEI}-\mathrm{C}_{18}(21)$

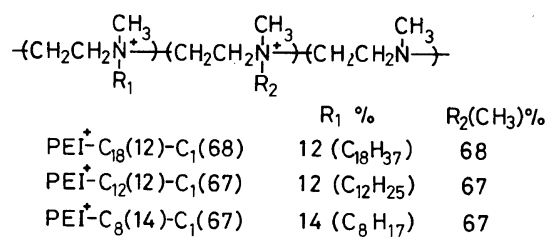

\section{EXPERIMENTAL}

\section{Materials}

$\mathrm{EVI}^{+}-\mathrm{C}_{12}(29)-\mathrm{C}_{2}(67)$ was prepared by the successive quaternization of poly(1-vinyl-2-ethylimidazole), using dodecyl bromide and ethyl bromide. ${ }^{7}$ The primary and secondary amino groups of commercial polyethylenimine $(25 \%$ primary, $50 \%$ secondary and $25 \%$ tertiary amino groups, $\left.M_{w}=40,000-50,000\right)$ were completely converted to tertiary amino groups by formic acid and formaldehyde and the resulting polymer was partially quaternized by alkyl halides. ${ }^{8}$ The preparation of bifunctional and monofunctional catalysts has already been reported. 5

\section{$p K_{\mathrm{a}}$ Determination}

The $\mathrm{p} K_{\mathrm{a}}$ values of the hydroxamate groups of LBHA and LIMHA were determined at $30^{\circ} \mathrm{C}$ in 3 $\mathrm{v} / \mathrm{v} \% \mathrm{EtOH}-\mathrm{H}_{2} \mathrm{O}, \mu=0.01(\mathrm{KCl})$ in the presence of $2.06 \times 10^{-3} \mathrm{~mol} \mathrm{dm}^{-3}$ of EVI ${ }^{+}-\mathrm{C}_{12}(29)-\mathrm{C}_{2}(67)$. The absorbance difference at $300 \mathrm{~nm}$ between the neutral and anionic species was used: for LBHA, $\varepsilon_{\mathrm{HA}}=96$ $\mathrm{mol}^{-1} \mathrm{dm}^{-3} \mathrm{~cm}^{-1}(0.01 \mathrm{~N}$ hydrochloric acid) and $\varepsilon_{\mathrm{A}}{ }^{-}=2100 \mathrm{~mol}^{-1} \mathrm{dm}^{-3} \mathrm{~cm}^{-1}(0.01 \mathrm{~N} \mathrm{NaOH})$, and for LIMHA, $\varepsilon_{\mathrm{HA}}=48 \mathrm{moldm}^{-3} \mathrm{~cm}^{-1}(0.01 N$ hydrochloric acid) and $\varepsilon_{\mathrm{A}-}=3780 \mathrm{~mol}^{-1} \mathrm{dm}^{-3} \mathrm{~cm}^{-1}$ $(0.01 N \mathrm{NaOH})$. The modified HendersonHasselbalch equation was applied,

$$
\mathrm{pH}=n^{\prime} \log \frac{\varepsilon_{\mathrm{A}}^{-}-\varepsilon}{\varepsilon-\varepsilon_{\mathrm{HA}}}+\mathrm{p} K_{\mathrm{app}}
$$

where $\varepsilon$ is the apparent extinction coefficient at $300 \mathrm{~nm}$ at a given $\mathrm{pH}$. The $\mathrm{p} K_{\mathrm{app}}$ values for LBHA and LIMAH are $8.78\left(n^{\prime}=1.30\right.$ and correlation coefficient $=0.991$ at $\mathrm{pH} 8.0-9.5)$ and $9.48\left(n^{\prime}=1.41\right.$ and correlation coefficient $=0.993$ at $\mathrm{pH} 9.0-9.8)$, respectively. These values are greater than those estimated in the CTAB system ${ }^{5}$ by $c a .0 .4 \mathrm{p} K$ units.

\section{Rate Measurement}

The hydrolysis of PNPA was performed at $30^{\circ} \mathrm{C}$ in $3 \mathrm{v} / \mathrm{v} \%$ EtOH$-\mathrm{H}_{2} \mathrm{O}$ with a $0.01 \mathrm{~mol} \mathrm{dm}^{-3}$ borate buffer having an ionic strength of $0.01(\mathrm{KCl})$. In the case of bifunctional catalysis, excess PNPA was present relative to LIMHA. The catalytic and uncatalyzed (spontaneous) rates were determined from the absorbance of $p$-nitrophenolate anion at $401 \mathrm{~nm}$. Pseudo first-order kinetics were applicable for more than $80 \%$ completion. In the case of monofunctional LBHA, the acylation and deacylation steps were examined separately. The acyl transfer rate to LBHA was obtained in a way similar to that mentioned above in the presence of excess nucleophile. The decomposition rate of acetyl LBHA was determined from the absorbance of the hydroxamate anion at $300 \mathrm{~nm}$.

\section{Apparatus}

Hydrolysis was investigated by using Hitachi UVvisible spectrophotometers (types 124 and 200) provided with thermostated cell holders. A ToaElectronics HM 10B digital pH meter was used for $\mathrm{pH}$ measurement.

\section{RESULTS AND DISCUSSION}

\section{Cooperative Action of Hydroxamate and Imidazole}

An example of the time course of the $p$ nitrophenol release in the presence of LBHA or LIMHA and a polysoap, EVI ${ }^{+}-\mathrm{C}_{12}(29)-\mathrm{C}_{2}(67)$, are shown in Figure 1. Excess PNPA (27 and 48 times relative to the nucleophiles) are present in both cases, and the uncatalyzed release is corrected. The curve for the LBHA system is composed of the fast release which approximately corresponds to the LBHA concentration and the subsequent slow, linear release. In contrast, a linear increase in $p$-nitrophenol is observed for the bifunctional (hydroxamateimidazole) system beyond the catalyst concentration. Similar trends are found at other $\mathrm{pH}$ 's ( $\mathrm{pH} 8-10$ ). The steeper slope of curve A relative to that of a curve $B$ indicates that acetyl transfer to LBHA is faster than that to LIMHA.

As already mentioned for the conventional micel- 


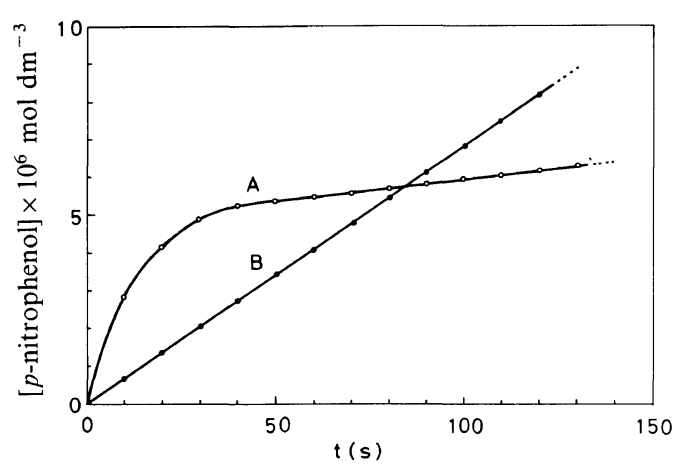

Figure 1. The time course of $p$-nitrophenol release: $30^{\circ} \mathrm{C} ; 3 \mathrm{v} / \mathrm{v} \%$ EtOH$-\mathrm{H}_{2} \mathrm{O} ; 0.02 \mathrm{~mol} \mathrm{dm}^{-3}$ borate buffer; $\mu=0.01(\mathrm{KCl})$. A (Monofunctional catalysis): $\mathrm{pH}, 8.06$; $[\mathrm{LBHA}]=6.96 \times 10^{-6} \mathrm{~mol} \mathrm{dm}^{-3} ;[\mathrm{PNPA}]=3.34 \times 10^{-4}$ $\mathrm{mol} \mathrm{dm}^{-3} ; \quad\left[\mathrm{EVI}^{+}-\mathrm{C}_{12}(29)-\mathrm{C}_{2}(67)\right]=2.90 \times 10^{-3}$ unit mol dm ${ }^{-3}$. B (bifunctional catalysis): $\mathrm{pH}, \quad 9.16$; $[$ LIMHA $]=7.29 \times 10^{-6} \mathrm{~mol} \mathrm{dm}^{3},[\mathrm{PNPA}]=2.00 \times 10^{-4}$ $\mathrm{mol} \mathrm{dm}^{-3} ; \quad\left[\mathrm{EVI}^{+}-\mathrm{C}_{12}(29)-\mathrm{C}_{2}(67)\right]=1.03 \times 10^{-3}$ unit mol dm ${ }^{-3}$

lar system, hydrolysis proceeds via the acetyl hydroxamate intermediate (scheme 1). The different kinetic behaviors between catalyses by LBHA and LIMHA are related to the fact that the decomposition of the acetyl intermediate is slow in the LBHA system and fast in the LIMHA system. The linear $p$-nitrophenol release for the latter suggests the occurrence of catalytic turnover. In fact, pseudo first-order kinetics could be observed for the whole range of the time course when a small excess of PNPA (several fold relative to LIMHA) was used.

Table I summarizes the effect of different polysoaps on the catalytic hydrolysis by LIMHA. The $p$-nitrophenol release was followed until nearly complete, and the second-order rate constant, $k_{\text {cat.obsd }}$, was obtained by dividing the pseudo first-order rate

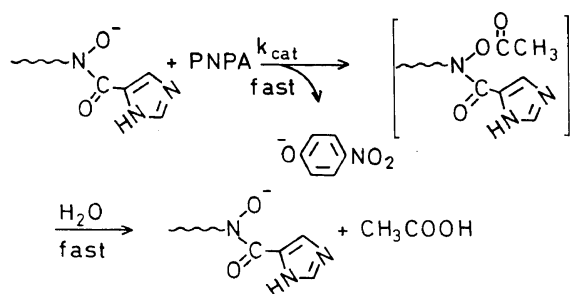

Bifunctional catalyst (LIMHA)

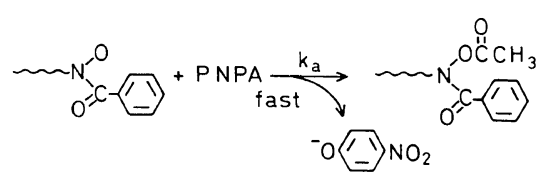

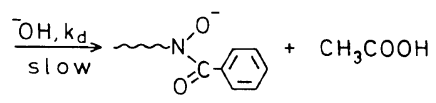

Monofunctional catalyst (LBHA)

Scheme I Catalytic mechanism

constant (as determined by the pseudo first-order plot) by the catalyst concentration. Among the polyethylenimine derivatives, $\mathrm{PEI}^{+}-\mathrm{C}_{18}(21)$ (polyethylenimine quaternized partly by octadecyl bromide) had the highest-rate constant. Further quaternization by methyl bromide made the polymer less effective (Entry 3 vs. 4). Polyethylenimine quaternized by octyl and methyl groups (Entry 1) produced but very little rate acceleration.

In the following, the two most effective polysoaps $\left[\mathrm{EVI}^{+}-\mathrm{C}_{12}(29)-\mathrm{C}_{2}(67)\right.$ and $\left.\mathrm{PEI}^{+}-\mathrm{C}_{18}(21)\right]$ were used. Apparently, the hydrophobic nature of polysoap is the most important factor in promoting catalytic hydrolysis. Visible spectra of methyl orange has been used to detect the hydrophobic domain of polysoaps, since $\lambda_{\text {max }}$ near $465 \mathrm{~nm}$ in water shifts to

Table I. Rate constants of catalytic and spontaneous hydrolysis ${ }^{\mathrm{a}}$

\begin{tabular}{|c|c|c|c|c|c|}
\hline \multirow{2}{*}{$\mathrm{pH}$} & \multirow{2}{*}{ Polysoap } & \multirow{2}{*}{$10^{3} \times$ unit $\mathrm{mol} \mathrm{dm}^{-3}$} & \multirow{2}{*}{$\frac{k_{\text {cat,obsd }},{ }^{\mathrm{b}}}{\mathrm{mol}^{-1} \mathrm{dm}^{3} \mathrm{~s}^{-1}}$} & \multirow{2}{*}{$\frac{10^{4} \times k_{\text {spont }}}{\mathrm{s}^{-1}}$} & \multirow{2}{*}{$\begin{array}{c}\lambda_{\max } \text { of } \\
\text { methyl } \\
\text { orange/nm }\end{array}$} \\
\hline & & & & & \\
\hline 9.14 & $\mathrm{PEI}^{+}-\mathrm{C}_{8}(14)-\mathrm{C}_{1}(67)$ & 1.45 & 32.0 & 3.51 & - \\
\hline 9.14 & $\mathrm{PEI}^{+}-\mathrm{C}_{12}(12)-\mathrm{C}_{1}(67)$ & 1.00 & 225 & 3.92 & $430(\operatorname{ref} 8)$ \\
\hline 9.17 & $\mathrm{PEI}^{+}-\mathrm{C}_{18}(12)-\mathrm{C}_{1}(68)$ & 1.30 & 180 & 4.70 & $426($ ref 8$)$ \\
\hline 9.19 & $\mathrm{PEI}^{+}-\mathrm{C}_{18}(21)$ & 0.97 & 443 & 4.30 & $418($ ref 8$)$ \\
\hline 8.95 & $\mathrm{EVI}^{+}-\mathrm{C}_{12}(29)-\mathrm{C}_{2}(67)$ & 0.74 & 376 & 3.25 & $417($ ref 6$)$ \\
\hline
\end{tabular}

a $30^{\circ} \mathrm{C}, 3 \mathrm{v} / \mathrm{v} \% \mathrm{EtOH}-\mathrm{H}_{2} \mathrm{O}, \mu=0.01(\mathrm{KCl}), 0.02 \mathrm{~mol} \mathrm{dm}{ }^{-3}$ borate buffer, $[\mathrm{PNPA}]=4.16 \times 10^{-5} \mathrm{~mol} \mathrm{dm}^{-3}$

b $\left[\right.$ LIMHA] $=7.29 \times 10^{-6} \mathrm{~mol} \mathrm{dm}^{-3}$ 
shorter wave lengths in the hydrophobic microenvironment. ${ }^{9}{ }^{910}$ We have shown that the decarboxylation rate ${ }^{6}$ and the reactivity of $\mathrm{LBHA}^{8}$ can be correlated with the $\lambda_{\max }$ value. The $k_{\text {cat,obsd }}$ value approximately correlates with $\lambda_{\max }$ in Table $\mathrm{I}$. $\mathrm{PEI}^{+}-\mathrm{C}_{18}(12)-\mathrm{C}_{1}(68)$ is expected to provide microenvironments that are more hydrophobic than that of $\mathrm{PEI}^{+}-\mathrm{C}_{12}(12)-\mathrm{C}_{1}(67)$ and this is born out by a smaller $\lambda_{\max }$ value for the former. However, $k_{\text {cat.obsd }}$ obtained in the presence of PEI ${ }^{+}-\mathrm{C}_{18}(12)-\mathrm{C}_{1}(68)$ is smaller than that obtained in the presence of $\mathrm{PEI}^{+}-\mathrm{C}_{12}(12)-\mathrm{C}_{1}(67)$. The reactivity of LBHA in the presence of these polymers showed maxima when the polymer concentration was varied. The octadecyl derivative enhanced the LBHA reactivity more efficiently than the dodecyl counterpart at lower polymer concentrations, but the reverse was true at higher polymer concentrations. ${ }^{8}$ The reason for this peculiar behavior is not known at the present. The present results on $k_{\text {cat.obsd }}$ may stem from the same cause.

The rate constants of the spontaneous hydrolysis $k_{\text {spont }}$ were almost constant.

\section{Influence of Reaction Conditions on Rate Constant}

Figure 2 shows the influence of the polysoap concentration on the rate constant. The $k_{\text {cat.obsd }}$ value determined as mentioned above gives a maximum at $(1 \sim 2) \times 10^{-3}$ unit mol $\mathrm{dm}^{-3}$ of $\mathrm{PEI}^{+}-\mathrm{C}_{18}(21)$. A similar maximum is found for a combination of LBHA and EVI ${ }^{+}-\mathrm{C}_{12}(29)-\mathrm{C}_{2}(67)$. The rate constant of acylation, $k_{\mathrm{a} . \text { obsd }}$, is obtained in the latter case, since LBHA is present in excess of PNPA. The dependence of $\alpha$ (fraction of hydroxamate anion) on the polysoap concentration is also shown for LBHA in Figure 2. The $\alpha$ value at the respective $\mathrm{pH}$ was calculated from eq 3 using $\mathrm{p} K_{\mathrm{app}}$.

$$
\alpha=\frac{1}{1+10^{\left(\mathrm{p} K_{\mathrm{app}}-\mathrm{pH}\right) / n^{\prime}}}
$$

The $\alpha$ variation corresponds quite well to the $k_{\mathrm{a}, \mathrm{obsd}}$ variation. Therefore, the change in the polysoap concentration causes the change in the amount of the dissociated hydroxamate group. A similar conclusion may be drawn for the LIMHA system.

The $\mathrm{pH}$-rate profiles in the presence of EVI ${ }^{+}-C_{12}(29)-C_{2}(67)$ are shown in Figure 3 for the catalytic rate constant $k_{\text {cat,obsd }}$ in the case of LIMHA, and for the rate constants of acylation and de-

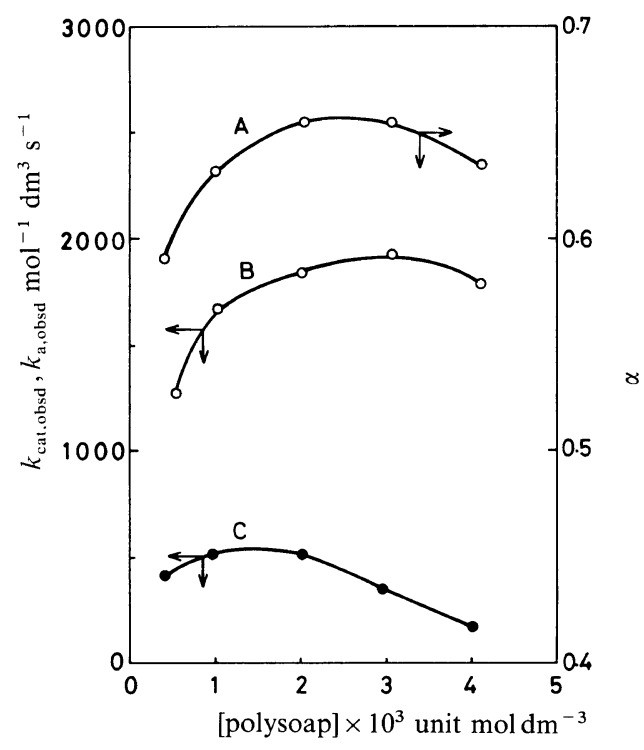

Figure 2. Effect of the polysoap concentration on the rate constant and the dissociation of $\mathrm{LBHA}: 30^{\circ} \mathrm{C} ; 3 \mathrm{v} / \mathrm{v}$ $\%$ EtOH $-\mathrm{H}_{2} \mathrm{O} ; 0.02 \mathrm{~mol} \mathrm{dm}{ }^{-3}$ borate buffer; $\mu=0.01$ $(\mathrm{KCl}) . \quad \mathrm{A}: \mathrm{pH} \quad 9.07 \pm 0.04, \quad[\mathrm{LBHA}]=6.12 \times 10^{-5} \mathrm{~mol}$ $\mathrm{dm}^{-3}, \mathrm{EVI}^{+}-\mathrm{C}_{12}(29)-\mathrm{C}_{2}(67)$. B: [PNPA] $=6.62 \times 10^{-4}$ mol dm ${ }^{-3}$. The other conditions are same as those of $A$. C: $\mathrm{pH} 9.00 \pm 0.17$; $\left[\right.$ LIMHA] $=7.29 \times 10^{-4} \mathrm{moldm}^{-3}$; $[\mathrm{PNPA}]=4.16 \times 10^{-5} \mathrm{~mol} \mathrm{dm}^{-3}$. Polysoap, $\mathrm{EVI}^{+}$ $\mathrm{C}_{12}(29)-\mathrm{C}_{2}(67)$.

acylation, $k_{\mathrm{a} \text {,obsd }}$ and $k_{\mathrm{d} \text {,obsd }}$, in the case of LBHA. $k_{\text {cat,obsd }}$ and $k_{\mathrm{a}, \text { obsd }}$ increase with $\mathrm{pH}$ in the same manner, reflecting increasing dissociation of the hydroxamate group. $\log k_{\mathrm{d} \text {,obsd }}$ increases linearly with increasing $\mathrm{pH}$. This indicates that the deacylation of acetyl LBHA is hydroxide-catalyzed.

The acetylation data of Figure 3 are replotted in Figure 4 using $k_{\text {cat,obsd }}$ (or $k_{\text {a.obsd }}$ ) and $\alpha$. In simple systems, the apparent acylation rate constant should be proportional to the fraction of the dissociated hydroxamate group. However, in Figure 4, the plots for LBHA appear to consist of two linear portions and those for LIMHA show an upward curvature. A similar curve has been found for LBHA in the presence of partly quaternized polyethylenimine $\left(\mathrm{PEI}^{+}-\mathrm{C}_{18}(12)\right),{ }^{8}$ but a linear relation was obtained for the CTAB system. ${ }^{5}$ Apparently, the microenvironment provided by the conventional globular micelle is not significantly perturbed by the incorporated long-chain hydroxamate, and the reactivity of the individual hydroxamate will be the 


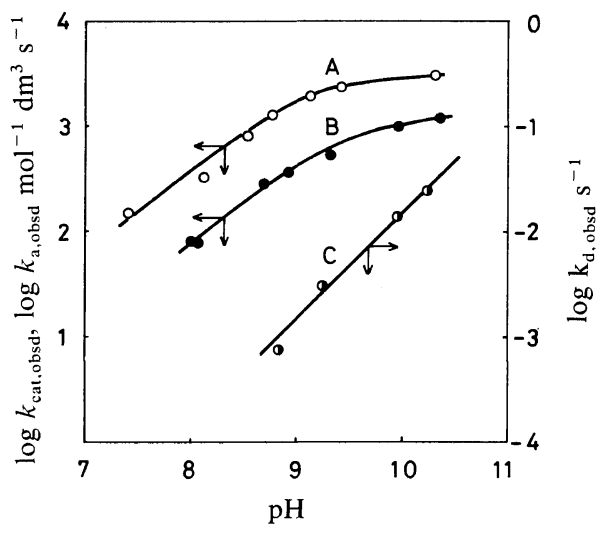

Figure 3. $\mathrm{pH}$-rate profiles of acylation and deacylation: $30^{\circ} \mathrm{C} ; 3 \mathrm{v} / \mathrm{v} \%$ EtOH$-\mathrm{H}_{2} \mathrm{O} ; 0.01-0.02 \mathrm{~mol} \mathrm{dm}^{-3}$ borate buffer; $\mu=0.01 \quad(\mathrm{KCl})$.

A (acylation): $[\mathrm{LBHA}]=6.12 \times 10^{-5} \mathrm{~mol} \mathrm{dm}^{-3}$; [PNPA] $=6.62 \times 10^{-6} \mathrm{~mol} \mathrm{dm}^{-3}$;

$\left[\mathrm{EVI}^{+}-\mathrm{C}_{12}(29)-\mathrm{C}_{2}(67)\right]=2.06 \times 10^{-3}$ unit mol $\mathrm{dm}^{-3}$. B (catalysis): $\left[\right.$ LIMHA] $=6.97 \times 10^{-6} \mathrm{~mol} \mathrm{dm}^{-3}$;

$[\mathrm{PNPA}]=7.57 \times 10^{-5} \mathrm{~mol} \mathrm{dm}^{-3}$;

$\left[\mathrm{EVI}^{+}-\mathrm{C}_{12}(29)-\mathrm{C}_{2}(67)\right]=7.40 \times 10^{-4}$ unit $\mathrm{mol} \mathrm{dm}^{-3}$.

$\mathrm{C}$ (deacylation): $[\mathrm{LBHA}-\mathrm{Ac}]=6.51 \times 10^{-5} \mathrm{~mol} \mathrm{dm}^{-3}$; $\left[\mathrm{EVI}^{+}-\mathrm{C}_{12}(29)-\mathrm{C}_{2}(67)\right]=2.06 \times 10^{-3}$ unit $\mathrm{mol} \mathrm{dm}^{-3}$.

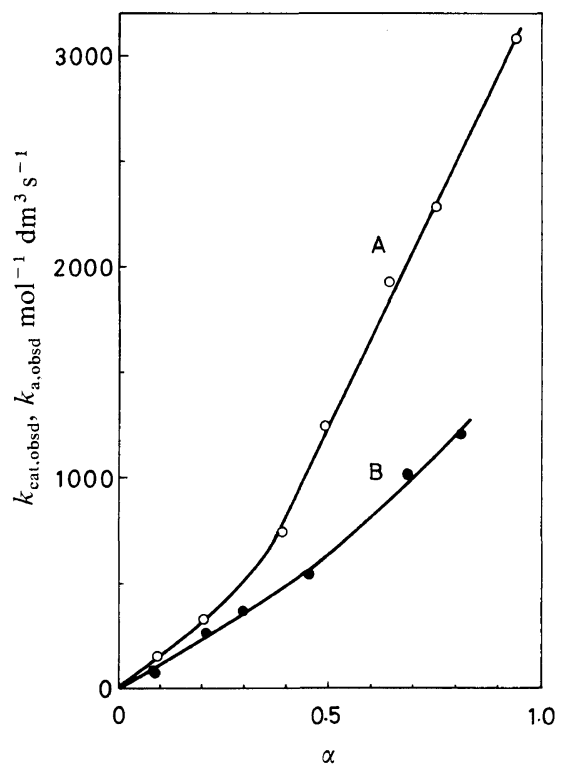

Figure 4. Dependence of the race constant on the fraction of the hydroxamate anion $(\alpha)$ : A, acylation of LBHA; B, catalysis by LIMHA. See text. $\alpha$ was calculated from eq 3 using $\mathrm{p} K_{\mathrm{app}}=8.78$ for LBHA and 9.48 for LIMHA. same. On the other hand, the hydrophobic domain of the polysoap is constructed of alkyl side chains much fewer in number than those in the conventional surfactant micelle: the aggregation number of $\mathrm{CTAB}$ is $30-40$. Therefore, the small hydrophobic domain of the polysoap should be strongly affected by the incorporation of hydrophobic nucleophiles and their degree of dissociation. As the dissociation of the nucleophile progresses, the hydrophobic nature of the microdomain must be strengthened due to the charge neutralization; This expains the upward curvature observed in Figure 4 and elsewhere. ${ }^{8}$

\section{Separation of Rate Constants of Acylation and} Deacylation

In the catalytic hydrolysis of esters where acyl intermediates are formed, the rate constant of the catalyst turnover, $k_{\text {cat.obsd }}$, is related to the rate constants of acylation and deacylation by eq $4 .{ }^{11.12}$

$$
k_{\mathrm{cat}, \text { obsd }}=\frac{k_{\mathrm{a}, \text { obsd }} k_{\mathrm{d}, \mathrm{obsd}}}{k_{\mathrm{a}, \text { obsd }}[\mathrm{ester}]_{0}+k_{\mathrm{d}, \mathrm{obsd}}}
$$

Thus,

$$
\frac{1}{k_{\text {cat }, \text { obsd }}}=\frac{[\text { ester }]_{0}}{k_{\mathrm{d}, \text { obsd }}}+\frac{1}{k_{\mathrm{a}, \text { obsd }}}
$$

and, $k_{\text {a.obsd }}$ and $k_{\text {d.obsd }}$ values can thus be estimated from the plot of $1 / k_{\text {cat.obsd }}$ and [PNPA] $]_{0}$.

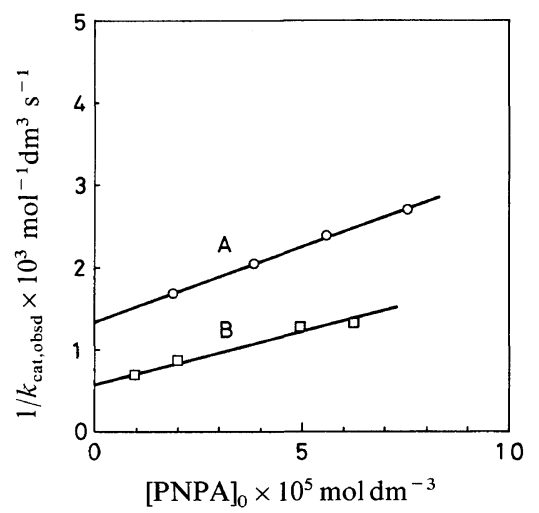

Figure 5. Plots of $1 / k_{\text {cat,obsd }}$ and the initial concentration of the substrate: $\mathrm{pH} 9.2 \pm 0.1,30^{\circ} \mathrm{C} ; \mathrm{v} / \mathrm{v} \%$ EtOH- $\mathrm{H}_{2} \mathrm{O} ; 0.02 \mathrm{~mol} \mathrm{dm}^{-3}$ borate buffer; $\mu=0.01(\mathrm{KCl})$; $\left[\right.$ LIMHA] $=1.18 \times 10^{-5} \quad \mathrm{~mol} \mathrm{dm}^{-3}$;

$\mathrm{A},\left[\mathrm{EVI}^{+}-\mathrm{C}_{12}(29)-\mathrm{C}_{2}(67)\right]=1.03 \times 10^{-3}$ unit mol dm ${ }^{-3}$, $r=0.998$;

$\mathrm{B},\left[\mathrm{PEI}^{+}-\mathrm{C}_{18}(21)\right]=1.13 \times 10^{-3}$ unit mol dm ${ }^{-3}, r=0.986$. 
Table II. Rate constants of acylation and deacylation ${ }^{a}$

\begin{tabular}{|c|c|c|c|c|c|}
\hline Catalyst & Polysoap & $\begin{array}{c}\mathrm{p} K_{\mathrm{a}} \text { of } \\
\text { hydroxamic acid }\end{array}$ & $\frac{k_{\mathrm{a}, \mathrm{obsd}}}{\mathrm{mol}^{-1} \mathrm{dm}^{3} \mathrm{~s}^{-1}}$ & $\frac{k_{\mathrm{d}, \mathrm{obsd}}}{\mathrm{s}^{-1}}$ & Remark \\
\hline LIMHA & $\begin{array}{l}\mathrm{EVI}^{+}-\mathrm{C}_{12}\left(29^{\prime}-\mathrm{C}_{2}(67)^{\mathrm{b}}\right. \\
\mathrm{PEI}^{+}-\mathrm{C}_{18}(21)^{\mathrm{b}} \\
\mathrm{CTAB}^{\mathrm{c}}\end{array}$ & $\begin{array}{l}9.48 \\
9.04\end{array}$ & $\begin{array}{r}750 \\
1750 \\
2050\end{array}$ & $\begin{array}{l}0.057 \\
0.081 \\
0.39\end{array}$ & $\begin{array}{l}\text { this work } \\
\text { this work } \\
\text { ref } 5\end{array}$ \\
\hline LBHA & $\begin{array}{l}\mathrm{EVI}^{+}-\mathrm{C}_{12}(29)-\mathrm{C}_{2}(67) \\
\mathrm{PEI}^{+}-\mathrm{C}_{18}(21)^{\mathrm{d}} \\
\mathrm{CTAB}^{\mathrm{c}}\end{array}$ & $\begin{array}{l}8.78 \\
8.71 \\
9.41\end{array}$ & $\begin{array}{l}1900 \\
2000 \\
1900\end{array}$ & $\begin{array}{l}0.0029 \\
0.0057 \\
0.0015\end{array}$ & $\begin{array}{c}\text { this work } \\
\text { ref } 8 \\
\text { ref } 5\end{array}$ \\
\hline
\end{tabular}

${ }^{\mathrm{a}} \mathrm{pH} 9.0 \pm 0.2,30^{\circ} \mathrm{C}, 3 \mathrm{v} / \mathrm{v} \%$ EtOH$-\mathrm{H}_{2} \mathrm{O}, \mu=0.01(\mathrm{KCl})$.

b Rate constants determined from eq 5 .

The $k_{\text {cat.obsd }}$ value decreased with increasing substrate concentrations under otherwise constant reaction conditions in accordance with eq 4 . Figure 5 gives plots of $1 / k_{\text {cat.obsd }}$ against [PNPA] $]_{0}$ for two polysoap systems. From the linear relations, $k_{\text {a.obsd }}$ and $k_{\text {d,obsd }}$ were determined by using eq 5 and are given in Table II. Table II also contains $k_{\text {a.obsd }}$ and $k_{\mathrm{d}, \text { obsd }}$ values for LBHA which were determined separately.

\section{Comaparison of Bifunctional Catalyses in the Micellar and Polysoap Systems}

The principal catalytic process of the hydrolysis of PNPA by LIMHA is the same in the CTAB micelle system and in the polysoap system, and is expressed by scheme 1 . As can be seen from Table II, polysoap is less effective than $\mathrm{CTAB}$ in enhancing rate constants, and the kinetics of the polysoap system are more complex than that of the other. A possible reason for this was given above.

General base mechanism

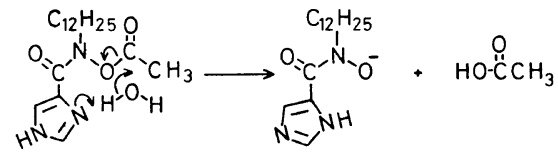

Acyl transfer mechanism

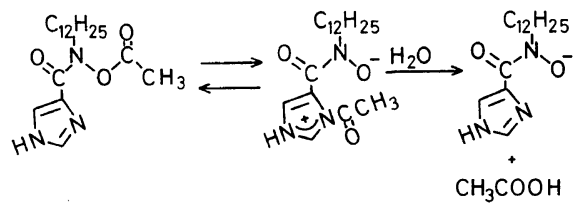

Scheme 2 Deacylation mechanism
Because of this complexity, more detailed kinetic analyses on the acylation and deacylation processes were difficult.

The deacylation rate of acetyl LBHA increases in the order of $\mathrm{PEI}^{+}-\mathrm{C}_{18}(21)>\mathrm{EVI}^{+}-\mathrm{C}_{12}(29)-\mathrm{C}_{2}(67)$ $>$ CTAB (Table II). Apparently, the unquaternized amino group in the polysoap accelerates the decomposition of the acetyl hydroxamate intermediate. However, these amino groups are much less effective than the imidazole group of LIMHA as can be seen from the $c a .15$ fold difference in $k_{\mathrm{d} . o b s d}$. The imidazole group may accelerate deacylation either by the general base catalysis or by the nucleophilic catalysis as shown in scheme 2. Although mechanistic differentiation cannot be made owing to the complexity of the micellar system, the general base mechanism appears more probable since this mechanism has been verified in several bifunctional (hydroxamate-imidazole) systems. ${ }^{2.3 .5}$

The efficiency of the intramolecular imidazole catalysis is greater in CTAB than in polysoaps: $k_{\mathrm{d}, \text { obsd }}=0.4 v s .0 .06-0.08 \mathrm{~s}^{-1}$. This is explained as follows: It has been suggested that the acetyl hydroxamate intermediate is effectively decomposed by the intramolecular imidazole anion. ${ }^{5}$ The $\mathrm{p} K_{\mathrm{a}}$ value of the hydroxamic acid of LIMHA is higher in polysoaps by $0.3-0.4 \mathrm{p} K$ unit than that in CTAB. The $\mathrm{p} K_{\mathrm{a}}$ value of the imidazole group will be similarly higher in polysoaps than in $\mathrm{CTAB}$, and the fraction of the anionic species will be smaller in the former system at a given $\mathrm{pH}$. In addition, the acetyl hydroxamate will become more stable with increasing $\mathrm{p} K_{\mathrm{a}}$ of the hydroxamic acid. These two factors will contribute to less efficient deacylation in the polysoap system. 
In conclusion, the efficiency of a hydrophobic bifunctional catalyst (hydroxamic acid-imidazole) is considerably enhanced in the presence of cationic polysoaps. This is basically derived from the formation of the hydrophobic ion pair mentioned above. ${ }^{5}$ The $k_{\text {cat,obsd }}$ value for the combination of LIMHA with $\mathrm{PEI}^{+}-\mathrm{C}_{18}(21)$ is about 1000 times larger than that of imidazole under similar conditions. However, the extent of rate enhancement was smaller than in the CTAB system. The hydrophobic domain of the polysoap appears to be perturbed more readily than that of the CTAB micelle. It may be necessary to lower the side-chain mobility in order to obtain a fundamentally new bifunctional catalyst in the polysoap system.

\section{REFERENCES}

1. T. Kunitake and Y. Okahata, Adv. Polym. Sci., 20, 161 (1976).
2. T. Kunitake, Y. Okahata, and T. Tahara, Bioorg. Chem., 5, 155 (1976).

3. Y. Kitaura and M. L. Bender, Bioorg. Chem., 4, 237 (1975).

4. T. Kunitake and Y. Okahata, J. Am. Chem. Soc., 98, 7793 (1976).

5. T. Kunitake, Y. Okahata, and T. Sakamoto, J. Am. Chem. Soc., 98, 7799 (1976).

6. T. Kunitake, S. Shinkai, and S. Hirotsu, J. Org. Chem., 42, 306 (1977).

7. S. Shinkai and T. Kunitake, Biopolymers, 15, 1129 (1976).

8. Y. Okahata and T. Kunitake, J. Polym. Sci., Polym. Chem. Ed., 16, 1865 (1978).

9. I. M. Klotz, G. P. Royer, and A. R. Sloniewsky, Biochemistry, 8, 4752 (1969).

10. T. Takagishi, Y. Nakata, and N. Kuroki, J. Polym. Sci., Polym. Chem. Ed., 12, 807 (1974).

11. M. L. Bender, F. J. Kézdy, and F. C. Wedler, J. Chem. Educ., 44, 84 (1967).

12. M. L. Bender and T. H. Marshall, J. Am. Chem. Soc., 90, 201 (1968). 